International Business and Global Economy 2018, no. 37, pp. 215-230

Biznes międzynarodowy w gospodarce globalnej 2018, nr 37, s. 215-230

Edited by the Institute of International Business, University of Gdańsk

Hans H. Bass

City University of Bremen

Marko Malovic

Educons University, University of Sarajevo

Deusdedit Rwehumbiza

University of Dar-es-Salaam

\title{
A common currency for the East African community? Lessons from the introduction of the euro
}

The paper analyses the feasibility of a common currency for the East African Community (EAC), which comprises Burundi, Kenya, Rwanda, South Sudan, Tanzania, and Uganda. The paper discusses theoretical insights on the benefits and costs of a common currency. It then uses the introduction of the common European currency, the euro, as a potential yardstick to assess the feasibility of a common currency in East Africa. The paper analyses the readiness of the EAC's economies for a common currency as measured by relevant indicators. It concludes that some caveats are in order with regard to the feasibility of a common East African currency at the present point in time. It also warns that expectations of the development impact of a common currency should not be too high, as the example of the euro shows that the real outcome in terms of trade facilitation and consumer welfare is much lower than expected.

Keywords: regional integration, monetary integration, optimum currency area, exchange rate regimes, East Africa

JEL classification: E42, F33, F36, F53

\section{Wspólna waluta dla wspólnoty Afryki Wschodniej? Lekcje płynące $\mathrm{z}$ wprowadzenia euro}

W niniejszym artykule analizuje się ideę wprowadzenia wspólnej waluty dla Wspólnoty Wschodnioafrykańskiej, w skład której wchodzą Burundi, Kenia, Rwanda, Sudan Południowy, Tanzania i Uganda. Omawia się w nim korzyści i koszty wynikające z wprowadzenia wspólnej waluty, traktując doświadczenia z wprowadzenia euro jako punkt odniesienia przy ocenie wykonalności takiego zamierzenia w Afryce. Ponadto poprzez analizę odpowiednich wskaźników przeprowadza się ocenę gotowości gospodarek wschodnioafrykańskich do wprowadzenia wspólnej waluty. Z przeprowadzonej analizy wynika, że istnieją powody, by do idei tej podchodzić bardzo ostrożnie. Równocześnie ostrzega się, by oczekiwania dotyczące wpływu wspólnej waluty na rozwój społeczno-ekonomiczny nie były zbyt wygórowane, gdyż - jak pokazuje wpro- 
wadzenie euro - rzeczywiste efekty w obszarze wymiany handlowej i korzyści konsumenckich były mniej znaczące od oczekiwanych.

Słowa kluczowe: integracja regionalna, wspólna waluta, optymalny obszar walutowy, kursy wymiany, Afryka Wschodnia

Klasyfikacja JEL: E42, F33, F36, F53

\section{Introduction}

Cross-border political and economic cooperation in East Africa has a long history, which includes both times of high hopes and serious setbacks. When after World War I the British had become the colonial power also in formerly German East Africa, they formed a customs union between all their East African possessions: the Colony and Protectorate of Kenya, the Uganda Protectorate, and the newly acquired Tanganyika Territory. Cross-territorial cooperation was intensified in the final decades of colonial authority by the East African High Commission (EAHC, 1948-1961) and its successor organisation in the transition period from colonial status to independence, the East African Common Services Organization (EASCO, 1961-1967). These institutions provided, i.a., a common currency, the East African shilling. It was in use until 1969, i.e., also during the first years of independence, or the end of the protectorate status (Tanganyika: 1961, Uganda: 1962, Kenya: 1963, Zanzibar: 1963).

In spite of the original attempts to form a political federation between the three territories (Tanganyika and Zanzibar had merged and become the United Republic of Tanzania in 1964), EASCO ran into difficulties. The reasons included the economic dominance of Kenya and the disagreement between the member states on fiscal policies. Therefore, in 1967 EASCO was superseded by a looser form of integration, the East African Community (EAC). Ten years later this organisation also nearly collapsed. This time, causes included the demands by Kenya for more seats than Uganda and Tanzania in decision-making organs, Tanzania's support for opposition forces which aimed to topple the regime of Uganda's self-declared president Idi Amin, as well as the increasing disparity of the economic systems which had been adopted in Tanzania and Kenya ("socialism" versus "capitalism").

At the turn of the new millennium, however, the EAC could be revitalized. Former rivalries between the three founding countries had become less pronounced. In the following years, three more countries joined the community: Burundi and Rwanda in 2009 and South Sudan in 2016. However, two of the three new member states face substantial political instability. In 2015, Burundi was at the brink of a civil war [Jeune Afrique, 2015]. In South Sudan, only recently an even if fragile ceasefire in its open civil war has been achieved [Jeune Afrique, 2018]. 
Nevertheless, the EAC is the continent's regional framework which has made the greatest progress in economic integration between member states. This can be shown by the UNECA index of regional integration [UNECA, 2016], which covers 16 indicators in five fields: trade integration, productive integration, financial and macroeconomic integration, the free movement of people, and the development of a regional infrastructure. According to this index, the EAC's position $(0.54$ out of a potential maximum of 1.00 index points) is ahead of the Southern African Development Community (0.53) and the Economic Community of West African States (0.51). All other African integration schemes have performed even lower.

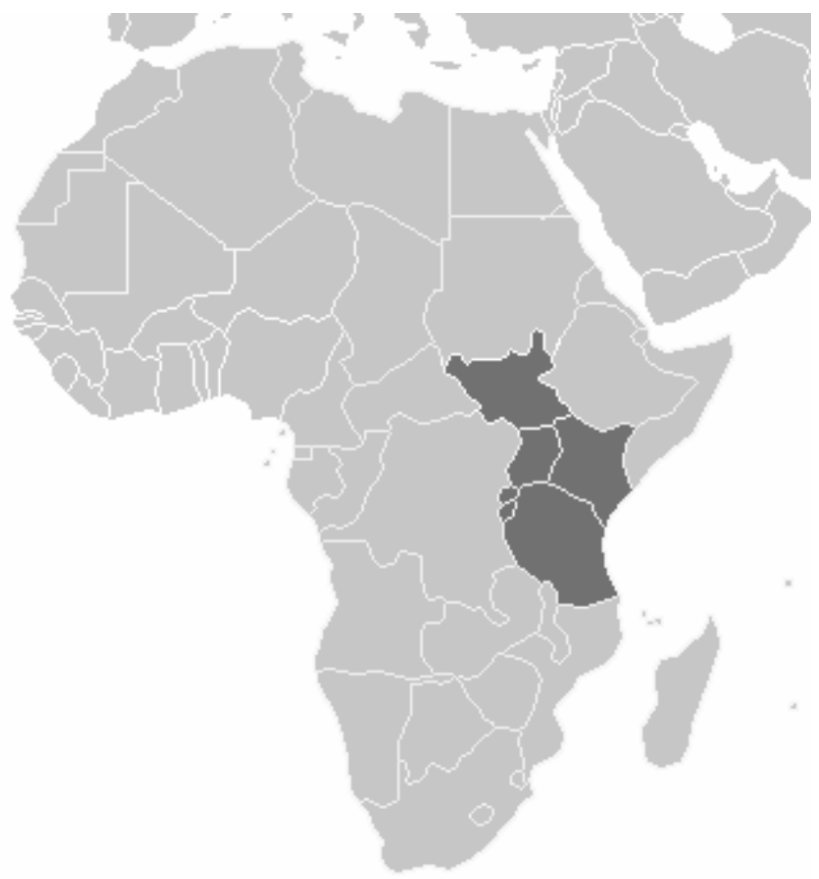

Figure 1. Map of Africa, highlighting the EAC countries

Source: [Wikimedia].

In the past few years, plans for a new common currency have even been developed within the EAC [UNECA, 2012]. Initially, it had been proposed that a (new) East African shilling should be introduced into circulation already in 2012, but this target was not met. A second target date was also not met. Finally, in 2013 a protocol was signed to create the East African Monetary Union (EAMU) by 2024 [Asongu, Nwachukwu, Tchamyou, 2016]. Political support for this idea is strong, and according to recent press releases, the "EAC vision for the common currency" seems actually to take shape [Nkwame, 2017; The East African, 2018]. 
The proposed formal membership criteria of the East African Monetary Union are more or less arbitrarily chosen macro-economic indicators and similar to the membership criteria of the European Economic and Monetary Union ("euro area").

Table 1. Membership criteria of the European and the East African monetary unions

\begin{tabular}{|l|l|l|}
\hline \multicolumn{1}{|c|}{ Membership criteria } & \multicolumn{1}{c|}{ EAMU } & \multicolumn{1}{c|}{ EMU } \\
\hline inflation rate (in \%) & $<8$ & $\begin{array}{l}<1.5 \text { points above best } \\
3 \text { members }\end{array}$ \\
\hline fiscal deficit (as \% of GDP) & $<3$ & $<3$ \\
\hline overnment debt (as \% of GDP) & $<50$ & $<60$ \\
\hline other & $\begin{array}{l}\text { monetary reserves cover } \\
4.5 \text { months of import }\end{array}$ & $\begin{array}{l}\text { exchange rate stability, } \\
\text { interest rate harmonization }\end{array}$ \\
\hline
\end{tabular}

Source: [European Commission data; East African Community data; The East African, 2018].

An open research question, however, is whether a common East African currency at this point in time is economically reasonable. To answer this question, the present paper in its section 1 refers to the optimum currency area (OCA) theory. It argues that a high degree of "real" economic convergence between the potential members of a single currency area is the precondition for the benefits of a common currency outweighing its drawbacks. In section 2 we turn towards a comparison case for the EAMU - the euro area, which is arguably the world's most prominent common currency scheme. We analyse the degree of convergence between the twelve original members which adopted the common currency in 1999-2001 and argue that some of the present problems of the euro area result from the disregard of the insights from the OCA theory. Section 3 analyses the present degree of economic convergence between the prospective EAMU members. The last section draws conclusions.

\section{Potential benefits and costs of a common currency}

A common currency comes with benefits and costs. Potential gains from a common currency for the participating economies may result from three factors. First, a common currency will reduce cross-border transaction costs. This means that both simpler and cheaper capital transfers and simpler and cheaper crossborder trade between the participating economies in goods and services can be expected. Secondly, the exchange rate risk for exporters and importers across the national borders of the participating economies will be eliminated. This may result in a more rational investment behaviour due to the reduction of uncertainty and may increase the efficiency of transnational capital markets. Thirdly, a common 
currency can provide welfare effects for consumers. In the short run, decreasing trade costs along with an increasing competition of enterprises across borders will contribute to lower end-user prices. In the long run, incentives for companies will be created to expand production to achieve economies of scale, as in addition to previous steps of integration further trade barriers fall and thus markets become larger. All in all, gains from a common currency basically accrue on a microeconomic level.

On the other hand, potential losses from a common currency will mostly accrue on the macro-level. First, flexible exchange rates between the participating countries are a potential tool for national macro-economic stabilization in case of asymmetric shocks within the common currency area. This tool will vanish in a common currency area. Secondly, problems in the timing of the common monetary policies, such as interest rate policies, may emerge. In the case of asynchronous business cycles, "one size (of a monetary policy) does not fit all", but a differentiation of monetary policies is no longer possible. Thirdly, incentives to violate fiscal discipline will emerge. The reason is that fiscal policy remains the only tool for national anti-cyclical policies. Fourthly, an unforeseen (and often unwanted) dynamism in the transfer of national rights to supranational institutions may occur which may cause political discontent among citizens.

In general, the stronger the economic ties between the participating economies, the more gains can be expected from a common currency, and vice versa. The critical degree of economic integration is when micro-economic gains from a common currency equal macro-economic losses from a common currency. A geographic area where the real economic convergence (or economic integration) is greater than this critical degree is defined as an "optimum currency area" (OCA) - a somewhat misleading term, as no optimization problem is implied. Or, to put it differently, the condition for optimality may be that the constituent members of the monetary union are better off with a common currency rather than without it, implying that no member has the incentive to abandon the monetary union [Demopoulos, Yannacopoulos, 1999].

The idea of an optimum currency area dates back to Mundell [1961]. Henceforth the question of how to measure the required degree of real convergence between two participating political entities (whether two countries or one country and a number of other countries already forming a common currency area) has been answered in different ways. First-generation indicators of real integration [Mundell, 1961; McKinnon, 1963] have included high labour mobility, high flexibility of wages and prices, high degree of intra-bloc trade, and high share of "tradables" in GDP. Second-generation criteria of the feasibility of a monetary union [Kenen, 1969; Ingram, 1969] have included high degree of diversification of production and thus insignificant terms-of-trade effects in case of sectoral external 
shocks, preparedness for fiscal transfers between countries, high capital mobility, and strong synchronisation of business cycles. In addition, similarity of political values with respect to monetary stability and similarity of political values with respect to prudent fiscal policies have been mentioned as further relevant criteria.

The creation a common currency scheme which intentionally or unintentionally disregards these insights will lead into serious difficulties for the participating economies [Krugman,2012]. This will be shown by the example of the euro area in the next section.

\section{The relevance of economic convergence - the case of the euro area}

The euro area is arguably the world's most prominent endeavour to create a common currency scheme. To briefly assess the degree of convergence between the founding members of the EMU, this paper looks into labour mobility and the synchronization of business cycles.

Table 2. Unemployment rates in sub-national regions of the euro area and the US

\begin{tabular}{|l|r|r|}
\hline \multicolumn{1}{|c|}{ Indicator } & US, 2005 & Euro area, 2004 \\
\hline total of unemployment (\%) & 5.1 & 8.9 \\
\hline number of regions & 367 & 255 \\
\hline standard deviation of regional unemployment rates (\%) & 1.6 & 6.1 \\
\hline coefficient of variation & 0.31 & 0.69 \\
\hline region with lowest unemployment rate (\%) & 2.7 & 2.2 \\
\hline region with highest unemployment rate (\%) & 16.0 & 32.8 \\
\hline
\end{tabular}

Source: [Peters, 2006, p. 14].

Table 3. Bilateral correlations of the business cycle component ${ }^{1}$ of GDP growth in the euro area (1995-2014), Germany vis-à-vis other economies

\begin{tabular}{|c|c|c|c|c|c|c|}
\hline & GER & AUS & NLD & FRA & BLG & FIN \\
\hline GER & $\mathbf{1 . 0 0}$ & - & - & - & - & - \\
\hline AUS & $\mathbf{0 . 6 9}$ & 1.00 & - & - & - & - \\
\hline NLD & $\mathbf{0 . 6 0}$ & 0.93 & 1.00 & - & - & - \\
\hline FRA & $\mathbf{0 . 5 9}$ & 0.93 & 0.91 & 1.00 & - & - \\
\hline BLG & $\mathbf{0 . 5 7}$ & 0.97 & 0.94 & 0.95 & 1.00 & - \\
\hline FIN & $\mathbf{0 . 5 5}$ & 0.97 & 0.93 & 0.97 & 0.98 & 1.00 \\
\hline
\end{tabular}

\begin{tabular}{|c|c|c|c|c|c|c|}
\hline & GER & ITA & IRL & POR & SPA & GRC \\
\hline GER & $\mathbf{1 . 0 0}$ & - & - & - & - & - \\
\hline ITA & $\mathbf{0 . 5 0}$ & 1.00 & - & - & - & - \\
\hline IRL & $\mathbf{0 . 4 1}$ & 0.93 & 1.00 & - & - & - \\
\hline POR & $\mathbf{0 . 3 7}$ & 0.90 & 0.87 & 1.00 & - & - \\
\hline SPA & $\mathbf{0 . 2 7}$ & 0.95 & 0.90 & 0.90 & 1.00 & - \\
\hline GRC & $\mathbf{0 . 0 9}$ & 0.86 & 0.81 & 0.82 & 0.97 & 1.00 \\
\hline
\end{tabular}

Source: [De Grauwe, Ji, 2016, p. 11; OECD data].

1 Using a Hodrick-Prescott filter. 


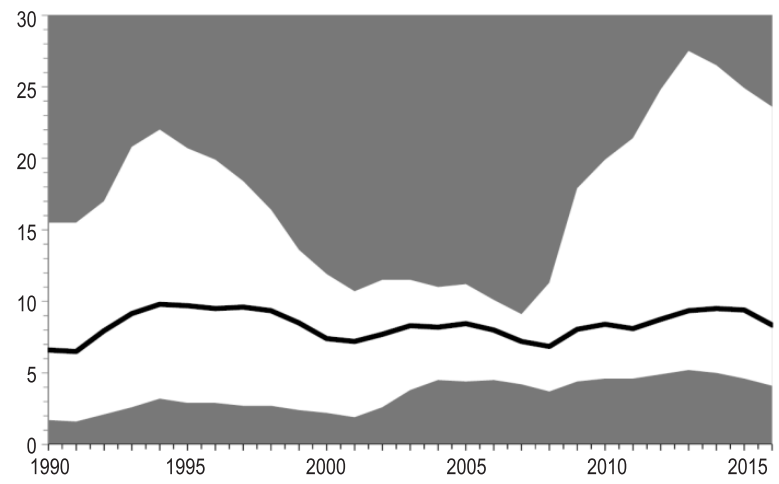

Figure 2. Differences in unemployment rates in the euro area (12)

Notes: The white corridor describes the gap between the country with the highest rate in one year and the country with the lowest rate in the same year. The thick line indicates the median value of the country rates. Unemployment rate is the share of unemployed in the working population.

Source: [Eurostat data].

First, the degree of labour mobility has been relatively low among the original member countries of the euro area (in 1999-2000: Austria, Belgium, Germany, Spain, Finland, France, Ireland, Italy, Luxemburg, Netherlands, Portugal and, in addition, Greece in 2002). Labour mobility can be indirectly measured by the differences in the unemployment rates of countries. Although the differences in the euro area decreased in the decade between the mid-1990s and the mid-2000s, on the sub-national level they remained much larger than in the benchmark case of the dollar area. After the global financial crisis, they increased again, indicating that labour mobility in the euro area was insufficient for levelling out.

Secondly, the synchronization of business cycles in the euro area has been relatively low. In particular, business cycles are not synchronized between the leading European economy (Germany) and other economies, especially those of Southern Europe. This means that anti-cyclical monetary policies which are appropriate for Germany tend to be not appropriate for Greece, Spain, or Portugal, and vice versa. Also, the GDP growth rates show high differences.

In short, the euro area was not an optimum currency area at its start and is still not today. The EMU membership criteria ("Maastricht criteria") disregarded much of the OCA scientific legacy and introduced a set of indicators instead, which were "arbitrary" in multiple respects. They are not supported by any other coherent piece of economic theory, it is unclear why specific numerical targets were chosen, or where it is clear, the reasoning is too linear, and there is an evident and arguably deliberate absence of real convergence criteria - in particular calibrated ones [Malovic, Djukic, Redzepagic, 2011, p. 13]. Although the Maastricht Treaty does enlist some of them (such as GDP per capita, balance of payments stance, employment, unit labour costs, competitiveness and the like, typically in 
footnotes and without quantification), the EMU cannot serve as a poster-child of real convergence criteria for qualifying into a currency union, simply because thus far most (if at all) of the existing members used them as a carte blanche to block or procrastinate new members from joining the euro area.

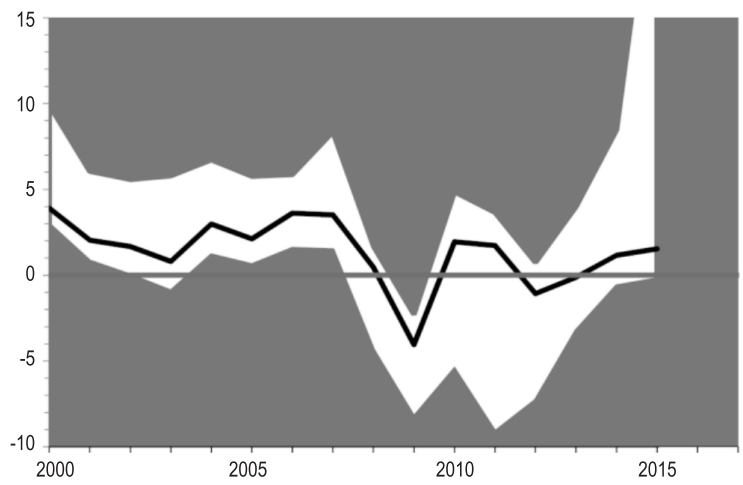

Figure 3. Differences in GDP growth rates in the euro area (12)

Notes: The white corridor describes the gap between the country with the highest rate in one year and the country with the lowest rate in the same year. The thick line indicates the median value of the country rates.

Source: [World Databank data].

Another view has emerged according to which a monetary union, by elimination of foreign exchange risk, currency conversion, and accompanying costs, gives significant impetus to intra-block trade as well as facilitates foreign direct investment which in turn may bring about further synchronization of national business cycles quite a while after joining the common currency area. This effect has been called "endogenous OCA-hypothesis effect" or "Rose effect" [Rose, 2000]. Crucial for the endogenous OCA-hypothesis is the extent of trade openness, the state of technology, and income level disparity. If disparities in those three properties are small to negligible, the Rose effect is expected to be reasonably large, with commerce intensifying, intra-industry trade dominating exchange flows, and growing incomes further converging to one another [Mongelli, 2002]. However, Rose has recently revised his position: "Estimates of the currency union effect on trade are sensitive to the exact econometric methodology; the lack of consistent and robust evidence undermines confidence in our ability to reliably estimate the effect of currency union on trade" [Glick, Rose, 2015]. Still, as far as the euro area is concerned, a Rose effect is not obvious. The share of intra-bloc trade had been very high before the introduction of the common currency, and has slightly decreased rather than increased after the formation of the EMU. The evidence on whether consumer prices converge or not is mixed ${ }^{2}$.

\footnotetext{
2 For a literature review see: [Macedoni, 2018, pp. 3-4].
} 


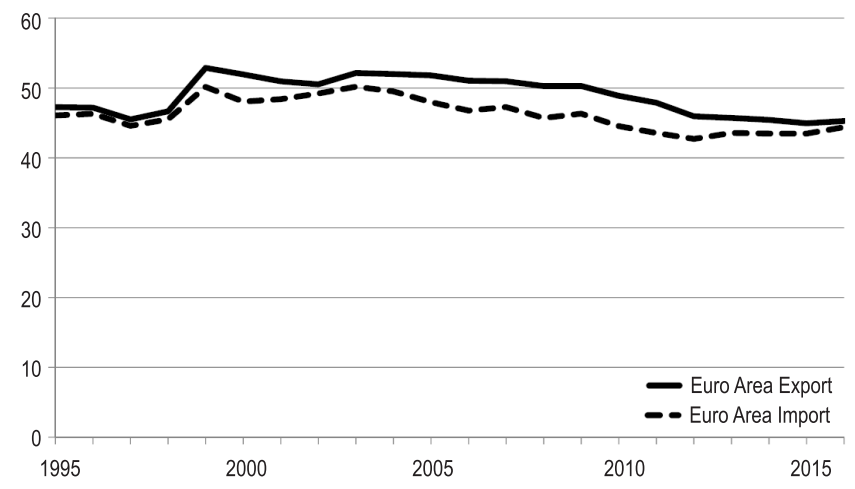

Figure 4. Intra-group trade as percentage of total trade in the euro area (different number of members $^{3}$ )

Source: [UNCTADstat data].

In contrast to the positive dynamics of a monetary union as predicted by the original Rose effect, also a negative development can take place. If the disparities in the degree of openness, the share of intra-industry trade (due to similar size of the economy and similar technology levels), and the income levels are substantial between the (potential) members of a currency union, then Krugman's [1993] specialisation effect may kick in, thereby debilitating the functionality of the monetary union. As a matter of fact, FX risk removal encourages economies of scale and industries with increasing returns which prompts the members of a monetary union to specialize along the comparative-advantage principle. Thus, technologically and competitiveness-wise the weaker members' production gradually becomes less diversified and more prone to supply-side shocks, whereas - in the context of the EMU - the core-periphery income gap widens [Mongelli, 2002]. Therefore, not only grey-zone members could move further away from the OCA line if they slipped into the currency union despite flopping the Kenen's criterion [Horvath, Komarek, 2002], but also clear-case qualified countries might spectacularly fail in satisfying OCA criteria ex post, even if they fulfilled them ex ante [Broz, 2005]. Needless to say, keeping heterogeneous economies within a single currency union is still possible despite the OCA criteria not having been met or indeed worsening a posteriori, but at the expense of more aggressive fiscal or pseudo-fiscal federalism [Obstfeld, Peri, 1998; Horvath, Komarek, 2002]. This is what seems to be happening in the euro area.

Thus it seems that the common European currency was the product of a strong political belief that economic integration should be crowned by a common cur-

3 The euro area covers the countries that signed the Maastricht Treaty and adopted the euro in 1999 (Austria, Belgium, Finland, France, Germany, Ireland, Italy, Luxembourg, Netherlands, Portugal, Spain), 2001 (Greece), 2007 (Slovenia), 2008 (Malta, Cyprus), 2009 (Slovakia), 2011 (Estonia), 2014 (Latvia), and 2015 (Lithuania). 
rency ("crowning theory") rather than a reflection of economic rationality. With this perspective in mind, the next section will look into the economic convergence within the EAC countries.

\section{Economic convergence in the EAC}

The East African Community countries are aspiring to form a currency union by 2024. Tanzania, Kenya, and Uganda are determined to merge their respective shillings with Rwanda's and Burundian francs as well as with the South Sudanese pound to forge a common legal tender in the bloc over the next six years, along with the establishment of a mutual central bank (the East African Central Bank) and the East African Statistics Bureau Bill shall create a regional agency akin to European Union's Eurostat, charged with gathering data to guide decision making within the EAC Monetary Union [The East African, 2018].

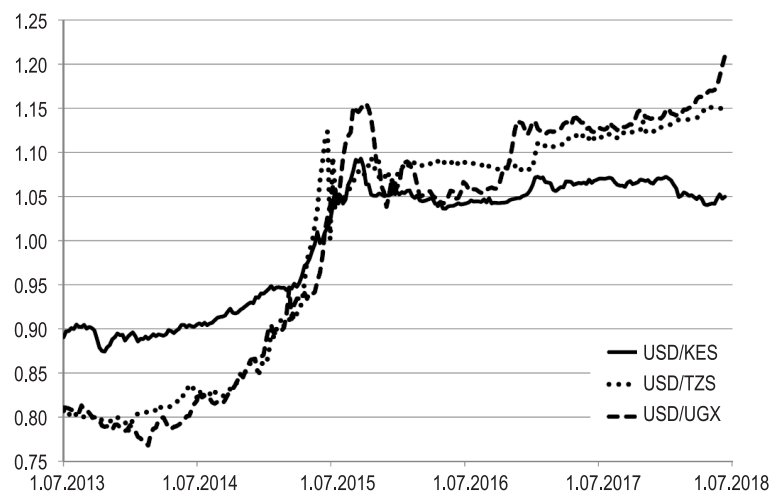

Figure 5. Standardized ${ }^{4}$ exchange rates of national currency to USD: Kenya, Uganda, and Tanzania, weekly

Source: Own elaboration based on: [OANDA].

The present exchange rate regimes in the EAC countries vary [IMF, 2016, pp. 6-7]. Tanzania floats it currency with a monetary aggregate target, Uganda floats with an inflation targeting framework, and Kenya floats with preliminary steps toward inflation targeting. A floating exchange rate is largely market determined, without an ascertainable or predictable path for the rate [IMF, 2016, p. 48]. In the aftermath of the global financial crisis, Burundi and Rwanda moved away from de jure floats to adopt less flexible exchange rate regimes. The IMF classifies Burundi's current exchange rate as a "stabilized arrangement". This entails a spot

4 Standardisation: per cent of total average. 
market exchange rate that remains within a margin of $2 \%$ for six months or more (with the exception of a specified number of outliers) and is not floating [IMF, 2016, p. 47]. Rwanda is classified as "other managed arrangement" (a residual category) with monetary aggregate target. South Sudan is also classified as "other managed arrangement", but has no explicitly stated nominal anchor and monitors various indicators in conducting monetary policies.

Table 4. Bilateral correlations of standardized exchange rates of national currency to EUR and EAC currencies, weekly, July 2013 to June 2018 ( $\mathrm{N}=259)$

\begin{tabular}{|l|c|c|c|c|c|c|}
\hline & EUR & BIF & KES & TZS & UGX & RWF \\
\hline EUR & 1.00 & 0.30 & 0.79 & 0.76 & 0.74 & 0.50 \\
\hline BIF & - & 1.00 & 0.67 & 0.73 & 0.75 & 0.93 \\
\hline KES & - & - & 1.00 & $\mathbf{0 . 9 8}$ & $\mathbf{0 . 9 8}$ & 0.81 \\
\hline TZS & - & - & - & 1.00 & $\mathbf{0 . 9 8}$ & 0.86 \\
\hline UGX & - & - & - & - & 1.00 & 0.87 \\
\hline RWF & - & - & - & - & - & 1.00 \\
\hline
\end{tabular}

Source: Own elaboration based on: [OANDA].

The loss of a country's ability to manipulate the exchange rate of its currency and to use national monetary policy for stabilisation purposes is widely believed to be the steepest cost of joining the common currency area. However, we now know this is arguably not the case for small open developing economies with flexible exchange rates, inflation targeting framework and capital mobility, whose monetary policy independence is in fact largely an illusion, due to policy contagion from and lock-step relationship with the activity of central bank whose currency is embraced by de facto dollarization [Edwards, 2015]. The exchange rates of the currencies of Kenya, Uganda, and Tanzania vis-á-vis the benchmark currencies USD and EUR already have been considerably harmonized by market forces between 2013 and 2018. The potential effect of a reduction of the exchange rate risk in trade between these three economies will thus tend to be rather small.

On the other hand, it is also a well-established fact that exchange rate volatility affects small companies more harshly than the big ones, so for smaller members of a currency union, the marginal impact of a removed foreign exchange rate risk is usually higher [Baldwin, Skudelny, Taglioni, 2005]. Thus the developmental impact of the common currency can be larger than the general impression suggests, as small and medium-sized enterprises (SMEs) in developing countries tend to be more labour-intensive than larger ones. Thus the relative stronger positive impact of a reduction of the FX risk for SMEs may help to promote a more "inclusive" growth.

When it comes to the formal membership criteria, it emerges that the EAC is not less prepared for a common currency than the euro area was at the introduction of the common currency. With the exception of Burundi, all EAC members 
tend to meet the criteria set for the fiscal balance. Gross government debt tends to be within the target and convergence is to be seen. The same holds true for consumer price inflation.
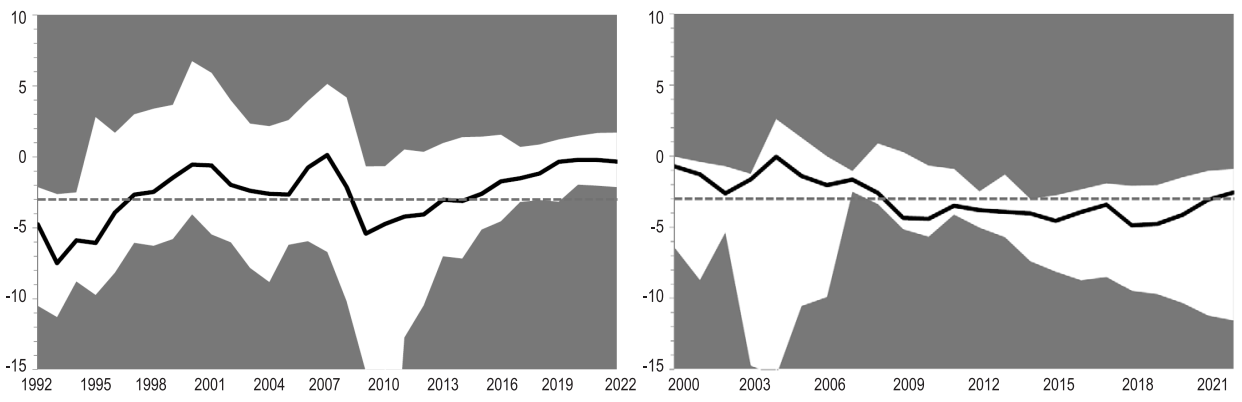

Figure 6. Fiscal balance; on the left the euro area (12), on the right the EAC (5)

Notes: Fiscal balance is the general government net lending/borrowing as percentage of GDP. The white corridor describes the gap between the country with the highest rate in one year and the country with the lowest rate in the same year. The thick line indicates the median value of the country rates, the dotted horizontal line indicates the target. The minimum fiscal balance in the euro area in 2010 is - $32 \%$ (for Ireland). The minimum fiscal balance in the EAC in 2004 is $-15 \%$ (for Burundi).

Source: [IMF; WEO data].
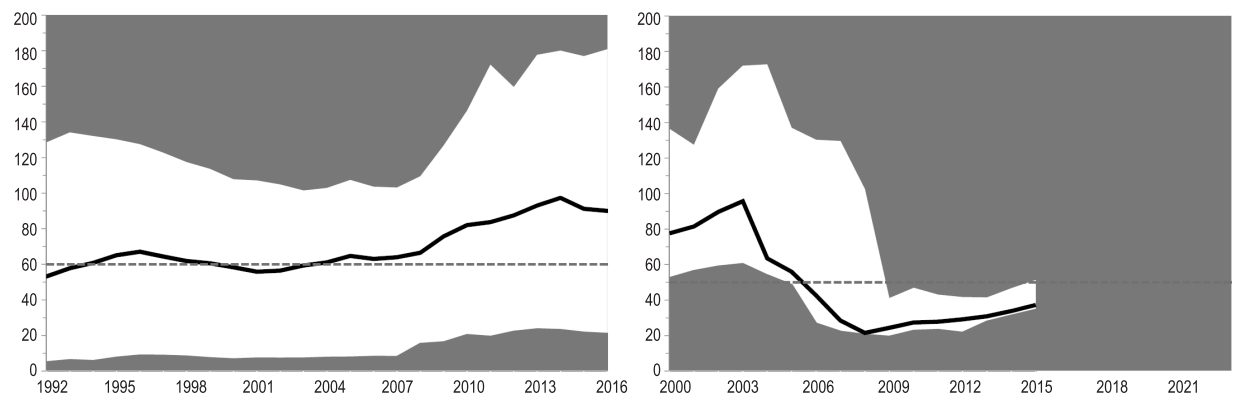

Figure 7. Gross government debt (as \% of GDP); on the left the euro area (12), on the right the EAC (5)

Notes: The white corridor describes the gap between the country with the highest rate in one year and the country with the lowest rate in the same year. The thick line indicates the median value of the country rates, the dotted horizontal line indicates the target.

Source: [IMF, Historical Public Debt Database; Eurostat].

However, when it comes to "real" convergence criteria, it seems that the EAC is not yet in a position to make the introduction of a common currency imperative. Given a strong similarity of comparative advantages in East African economies as well as the low development of cross-country infrastructure (especially roads) and bureaucratic hurdles, it comes as no surprise that the share of trade between EAC countries in total foreign trade is much lower than the respective share in the euro area. 

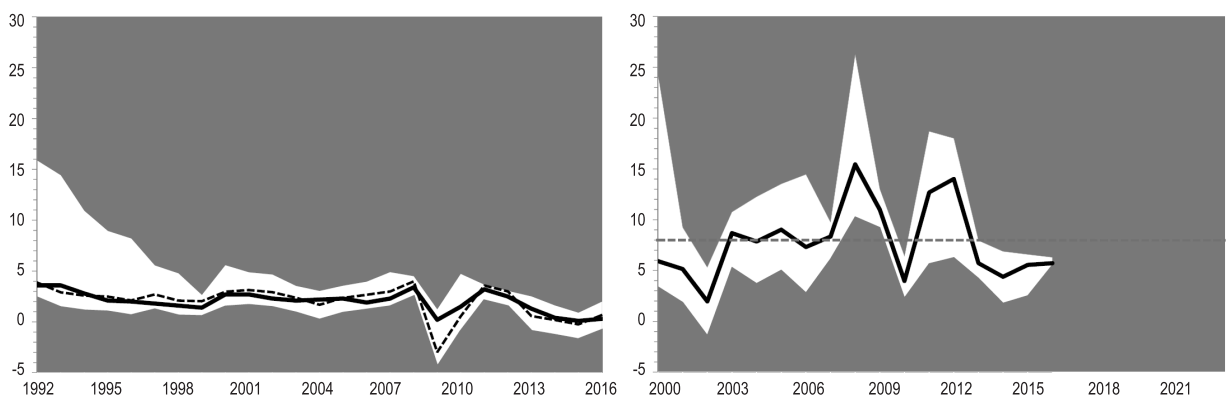

Figure 8. Inflation rates; on the left the euro area (12), on the right the EAC (5)

Notes: Inflation rate represents changes in consumer prices in percent. The white corridor describes the gap between the country with the highest rate in one year and the country with the lowest rate in the same year. The thick line indicates the median value of the country rates, the dotted line indicates the target.

Source: [World Development Indicators].

On the other hand, business cycles of the East African economies are strongly correlated. The reason may be the dominance of agriculture and thus the impact of similar weather conditions on all economies. More sophisticated measures referring to the co-integration of real effective exchange rates (1998-2010), however, suggest that the five East African countries tend to be affected by asymmetric shocks [UNECA, 2012, pp. 22-23]. The reason is that EAC countries are still heavily dependent on only a few export products, namely coffee and tea (except South Sudan), cut flowers (Kenya), gold (Tanzania), tobacco (Tanzania), non-ferrous ores (Rwanda), and crude petroleum (South Sudan). Thus, commodity price shocks are highly possible in the future. It could also be shown [Bass, Steinbeck, 2012] that the EAC countries were to a very different degree vulnerable to shocks originating in the euro area. While Kenya was extremely affected due to the concentration of its exports of commodities and tourism services on the euro area, Tanzania and Rwanda were much less influenced.

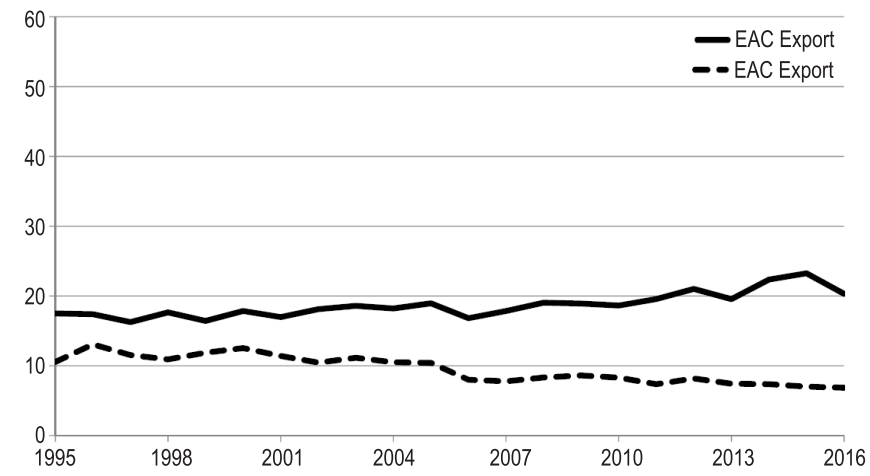

Figure 9. Intra-group trade as percentage of total trade, EAC

Data source: [UNCTADstat]. 
Table 5. Bilateral correlations of the business cycle component ${ }^{* 5}$ of GDP growth in EAC countries (2001-2009)

\begin{tabular}{|c|c|c|c|c|c|}
\hline & BDI & KEN & RWA & TZA & UGA \\
\hline BDI & 1.0 & - & - & - & - \\
\hline KEN & 0.8 & 1.0 & - & - & - \\
\hline RWA & 0.6 & 0.8 & 1.0 & - & - \\
\hline TZA & 0.2 & 0.5 & 0.9 & 1.0 & - \\
\hline UGA & 0.7 & 0.9 & 1.0 & 0.8 & 1.0 \\
\hline
\end{tabular}

Source: [UNECA, 2012, p. 22].

\section{Conclusions}

A nominal convergence to the set membership criteria for the EAMU seems to be possible for EAC countries by the set target year 2024. However, a real convergence in terms of high labour mobility, high intra-bloc trade (based on appropriate infrastructure), and efforts to build a strong resilience to external shocks would be much more important. Therefore, some caveats are in order with regard to the feasibility of a common East African currency at the present point in time. On the one hand, the exchange rates of the currencies of Kenya, Uganda, and Tanzania vis-á-vis the benchmark currencies USD and EUR have already been considerably harmonized by market forces. The potential effect of a reduction of the exchange rate risk in trade between these three economies will be rather small. On the other hand, the five East African countries tend to be affected by asymmetric shocks. In this case, the loss of a country's ability to manipulate the exchange rate of its currency and to use national monetary policy for stabilisation purposes is very costly. Finally, expectations of the development impact of a common currency should not be too high. The example of the euro shows that the real outcome in terms of trade facilitation and consumer welfare may be much lower than expected. To sum up, at the present point in time, an East African Monetary Union does not suggest itself.

\section{References}

Asongu S., Nwachukwu J., Tchamyou V., 2016, A literature survey on proposed African monetary unions, Journal of Economic Surveys, vol. 31, issue 3.

Baldwin R., Skudelny F., Taglioni D., 2005, Trade effects of the euro: Evidence from sectoral data, Economic Policy, ECB Working Paper no. 446.

Bass H.H., Steinbeck H.H., 2012, The euro crisis and macroeconomic policy formation in Africa, [in:] Macroeconomic policy formation in Africa, African Development Perspectives Yearbook, vol. 16.

\footnotetext{
5 Using a Hodrick-Prescott filter.
} 
Broz T., 2005, The theory of optimum currency areas: A literature review, Privredna kretanja i ekonomska politika, no. 104.

De Grauwe P., Ji Y., 2016, Flexibility versus stability, A difficult trade-off in the euro area, CEPS Working Document, no. 422, https://www.ceps.eu/system/files/WD422\%20De\%20 Grauwe\%20and\%20Ji\%20Flexibility\%20versus\%20Stability_0.pdf [access: 20.08.2018].

Demopoulos G.D., Yannacopoulos N.A., 1999, Conditions for optimality of a currency area, Open Economies Review, vol. 10.

Edwards S., 2015, Monetary policy independence under flexible exchange rates: An illusion?, NBER Working Paper no. 20893, Cambridge, MA.

Glick R., Rose A.K., 2015, Currency unions and trade: A Post-EMU mea culpa, http://www. frbsf.org/economic-research/files/wp2015-11.pdf [access: 20.08.2018].

Horvath R., Komarek L., 2002, Optimum currency area theory: An approach for thinking about monetary integration, Warwick Research Paper no. 647, University of Warwick.

Ingram J., 1969, Comment: The currency area problem, [in:] Monetary problems of the international economy, eds. R. Mundell, A. Swoboda, University of Chicago Press, Chicago-London.

IMF, 2016, International Monetary Fund, Annual report on exchange arrangements and exchange restrictions, https://www.imf.org/en/Publications/Annual-Report-on-ExchangeArrangements-and-Exchange-Restrictions/Issues/2017/01/25/Annual-Report-on-Exchange-Arrangements-and-Exchange-Restrictions-2016-43741 [access: 20.08.2018].

Jeune Afrique, 2015, Risques de guerre civile au Burundi, http://www.jeuneafrique.com/277563/ politique/risques-de-guerre-civile-burundi-conseil-de-securite-de-lonu-se-reunit-lundi/ [access: 20.08.2018].

Jeune Afrique, 2018, Soudan du Sud: Accord entre les belligérants pour retirer leurs forces des «zones urbaines», http://www.jeuneafrique.com/589639/politique/soudan-du-sud-lesbelligerants-daccord-pour-retirer-leurs-forces-des-zones-urbaines/ [access: 20.08.2018].

Kenen P., 1969, The theory of optimum currency areas: An eclectic view, [in:] Monetary problems of the international economy, eds. R. Mundell, A. Swoboda, University of Chicago Press, Chicago-London.

Krugman P., 1993, Lessons of Massachusetts for EMU, [in:] Adjustment and growth in the European monetary union, eds. F. Giavazzi, F. Torres, Cambridge University Press, New York.

Krugman P., 2012, Revenge of the optimum currency area, The New York Times, https://krugman.blogs.nytimes.com/2012/06/24/revenge-of-the-optimum-currency-area/ [access: 20.08.2018].

Macedoni L., 2018, Has the euro shrunk the band? Price convergence in a currency union, Aarhus University, http://www.lucamacedoni.com/uploads/7/2/1/9/72195123/euro_tar.pdf [access: 20.08.2018].

Malovic M., Djukic M., Redzepagic S., 2011, Maastricht criteria at the age of 18: Are they even converging, which party and to what end?, [in:] Serbia and the European Union: Economic lessons from the new member states, eds. J.S. Andrade et al., University of Coimbra, Coimbra.

McKinnon R., 1963, Optimum currency areas, The American Economic Review, vol. 53.

Mold A., Bagiza R., 2016, Building productive capacities for regional and global competitiveness: The case of the East African Community, [in:] Africa's progress in regional and global economic integration: Towards transformative regional integration, African Development Perspectives Yearbook, vol. 18. 
Mongelli F.P., 2002, New views on the optimum currency area theory: What is EMU telling us?, ECB Working Paper no. 138.

Mundell R., 1961, A theory of optimum currency areas, The American Economic Review, vol. 51, no. 4.

Nkwame M., 2017, East Africa: EAC Eyes Single Currency By 2024, AllAfrica, https://allafrica. com/stories/201711150165.html [access: 20.08.2018].

OANDA, [n.d.], https://www.oanda.com/lang/de/currency/converter/ [access: 01.06.2018].

Obstfeld M., Peri G., 1998, Regional Nonadjustment and Fiscal Policy: Lessons for EMU, NBER Working Paper no. 6431, https://core.ac.uk/download/pdf/6881378.pdf [access: 20.08.2018].

Peters H., 2006, Theorie optimaler Währungsräume vor dem Hintergrund der EU-Erweiterung, IÖB-Diskussionspapiere, University of Münster, Institute for Economic Education.

Rose A.K., 2000, One money, one market: The effect of common currencies on trade, Economic Policy, vol. 15, no. 30.

The East African, 2018, EAC vision for single currency takes shape, http://www.theeastafrican. co.ke/business/East-Africa-single-currency-takes-shape/2560-4389640-s8m4du/index. html [access: 20.08.2018].

UNECA, 2012, Towards a common currency in the East African Community: Issues, challenges and prospects, Addis Ababa, https://www.uneca.org/sites/default/files/PublicationFiles/ towards_a_common_currency_in_the_eac-2012.pdf [access: 20.08.2018].

UNECA, 2016, Africa regional integration index report, Addis Ababa, https://www.uneca.org/ sites/default/files/PublicationFiles/arii-report2016_en_web.pdf [access: 20.08.2018].

Wikimedia, [n.d.], Countries of the East African Community, https://upload.wikimedia.org/ wikipedia/commons/1/16/Africa-countries-EAC.png [access: 20.08.2018].

H.H. Bass ( $)$ hans-heinrich.bass@hs-bremen.de

City University of Bremen, Werderstrasse 73, 28199 Bremen, Germany

M. Malovic, Educons University, Serbia and University of Sarajevo,

Bosnia and Hercegovina

D. Rwehumbiza, University of Dar-es-Salaam, Tanzania 